\title{
Evaluations of port performances from a seaborne cargo supply chain perspective
}

\author{
Joyce M.W Low, Ph.D., Senior Lecturer \\ School of Air Transportation and Logistics, Korea Aerospace University \\ Shao Wei Lam, Ph.D. \\ Loon Ching Tang, Ph.D. Professor \\ Zhang Lan, B. Eng. \\ Department of Industrial and Systems Engineering, National University of Singapore
}

\begin{abstract}
Previous research on port efficiency focuses primarily on the provider's perspective and assumes that maximizing the output is always desirable. This paper recognizes that maximizing the final output does not necessarily guarantee an efficient system and the notion of port efficiency and service effectiveness needs to be considered from the perspectives of both the provider and the consumer of the port service. The paper proposes a network-DEA model to evaluate the performances of 30 seaports worldwide. The concurrent consideration of efficiency scores from the network-DEA model and the traditional DEA-CCR model will offer valuable insights to port operators on how to improve port performances as part of a seaborne cargo supply chain.
\end{abstract}

Key words: Seaborne cargo supply chain; Port efficiencies; Freight transportation; Port service benchmarking

\section{INTRODUCTION}

Adams Smith (The Wealth of Nations, 1776), in his discussion of specialization and the extent of the market, stresses the relationship between wealth and trade between nations. Despite some lingering controversy, empirical studies show a positive relationship between trade and growth (Clark, Dollar and Micco, 2004). At a global level, more than $85 \%$ of international trade volume is conducted by maritime transport ${ }^{1)}$. Compared to air and land modes, maritime transportation represents a viable and cost-effective way to transport a large amount of goods over long distance. Nagorski (1972), in his book "Port Problems in Developing Countries", advocates that an efficient and well-organized seaport would attract trade volume, facilitate economic growth, provide excellent sources for employment and generate significant foreign exchange earnings. In the era of globalization, seaports play an everincreasing important role in manufacturing and international business. Functioning as interfaces connecting the maritime and continental parts of the logistics chain, ports represent a growth pole with significant potential to trigger the economic prosperity of a nation. Conversely, a port can also become a major bottleneck and economic setback in the event of inferior performance.
Over the past four decades, the effectiveness of the maritime transport as a carrier of trade is further enhanced by containerization and advancements in logistics systems. While the port and maritime industry has grown significantly with trade, overlapping of the expanded port hinterlands, larger containerships and increased number of ports have also fueled competitions among ports. Port operators respond to the competition with an emphasis on the provision of services that matches to global competitiveness in terms of quality of services and overall efficiency of the port. These involve many aspects ranging from the reduction the vessel turnaround time to the efficient handling of customers' trucks so as to utilize the internal resources. In some cases, an expansion of port facilities or the construction of a new port may be necessary. As port development projects absorb large amounts of investment, the industry witnesses a paradigm shift and institutional reform towards the private sector's participation in ports. Along with this, the issue of port efficiencies gains importance owing to its impact on the investment return and international competitiveness of the ports (Low 2010).

The issue of port efficiencies has been dealt with by numerous scholars. Inherent in the measurement of port efficiency is the notion that a framework should be formulated to ensure multiple factors (inputs) and multiple goals (outputs)

1) In fact, a 2009 United Nations study reported that ocean shipping accounted for $66.3 \%$ of the world's merchandise trade in dollar terms (UNCTAD 2009). 
are adequately considered. A review of the literature showed that Data Envelopment Analysis (DEA) models dominate among the scientific methods of quantitative efficiency analysis that have been applied (see Table A-1). One of the major strengths of the DEA is that it enables the assessment of multi-factor productive efficiencies through an effective integration of multiple inputs and outputs factors within a single efficiency score. Particularly, DEA allows each decision making unit (DMU) to choose their own most favorable weights subject to the simultaneous consideration of other DMU's efficiency scores, relevant constraints and objectives instead of having a subjectively defined weight assigned a-priori in the computation of the efficiency score. Furthermore, this methodology neither imposes a parametric structure on data nor does it have heavy data requirements in terms of sample size. Data measured in different units can also be used simultaneously within a DEA model. Nonetheless, being an extreme point technique in which the efficiency frontier is formed by the actual performance of best performing observations, efficiency scores are highly sensitive to even small errors in measurement. Where sample size is small, it would result in a large proportion of observations having an efficiency score of 1. (Tone et al 2009 and Zhu 2009 provide a detailed theoretical discussion on the DEA methodology).

Apart from the DEA, econometric frontier analysis is another technique that has been used in the analysis of port efficiencies. For example, Coto Millán et al (2000) applied a translog function to 27 Spanish ports; Estache et al (2001) estimated a Cobb-Douglas and a translog production frontier for Mexican ports; Cullinane et al (2002) fitted a stochastic Cobb-Douglas production function to Asian ports among others. In comparison to the DEA methodology, econometric frontier analysis is disadvantaged in the sense that it requires a pre-specified functional form of the production or cost frontier (which may be ambiguous). As a statistical method, restrictive assumptions such as data normality, variable independences and residual randomness etc. also need to be satisfied when applying the econometric frontier analysis.

Despite the abundance of studies, application-related methodological improvements are relatively scant. More notably, most of the studies, if not all, share the common property that the efficiency of the system is evaluated as a whole. However, within a seaborne cargo supply chain, complexity arises from the fact that various factors and goals should be considered simultaneously. Particularly, there may be interactions among players with conflicting objectives that need to be addressed. It is not difficult to tell that the definitions for "efficient services" deviate, if not contradict, between the port service providers and the port users. From the viewpoint of the provider, efficiency is achieved when the port provides sufficient services at the least costs. Whereas according to the user, an efficient port is one which offers valued attributes such as shortest handling time or minimum damages to the containers. Service effectiveness can only be achieved if the service provided by a port is valued by the port users. Ships will call at their desired ports and the capacities provided by these ports are utilized by shippers and ocean liners, thereby generating cargo traffic in a port. To this end, it is meaningful to develop a method that is capable of measuring and evaluating the performance of port systems from the perspectives of the upstream and downstream players is necessary. The challenge remains on how to divide the system into the disaggregated processes, i.e., how to make sense of the input-output relationship between entities (or nodes) and the entire system.

This paper aims to accomplish the performance evaluation of port systems in an integrated framework that reflects the views of the provider and the user. The integrated framework utilizes a network-DEA formulation where the performance of a system and those of its component processes can be simultaneously measured. Specifically, the service provided and consumed in a container port creates an association between the provider and the user perspectives and hence it is chosen as the unit of analysis ${ }^{2)}$. As oppose to the conventional treatment of having individual ports as the DMUs, an inter-linked network of supply and demand nodes is used to represent these DMUs. The computation of efficiency of DMUs can be equivalently viewed as the computation of service effectiveness within this network of nodes that takes into account of both viewpoints. To the best of our knowledge, there has been no precedent of such model being used in the context of ports. As the industry globalizes, it has become imperative for port operators know their standing in a global scale. Thus, the study will proceed to measure and compare port performances in a sample consisting of major ports from Asia, Middle East, Europe and America.

Port authorities, actual transportation planners and port engineers could potentially be the users of the modeling framework proposed in this paper. Through this model, the performance of port is decomposed into two stages, from which one can further identify the sources of poor performance. For instance, from a provider's point of view, resources expended on port services need to be minimized for purpose of economization while ensuring adequacy for a smooth operation; from a consumer's point of view the handling capacity should be maximized to avoid congestion. Hence, achieving a delicate balance will ensure a port to be truly efficient.

The rest of the paper is organized as follows: The next section introduces the network-DEA model as a proposed conceptual framework that deals with "disaggregate" performance measurement, followed by the justifications for considering the provision of services in a container port as a DMU, assumptions and a mathematical representation of the model. Section 3 conducts the empirical study and compares the results between the network-DEA model and the traditional DEA-CCR model. Section 5 discusses the implications of the results and Section 6 concludes.

\section{THE MODEL}

\section{Conceptual Framework}

Fig. 1 is a graphical presentation of the conceptual framework of the system. In the diagram, the provision of port services is represented as a network of inter-linked nodes that is a result of both the provider's and user's decisions. Similar to other studies in the field, scarce resources (such as berth capacity and terminal area) are used as inputs for the production unit and services provided as outputs. As the evaluation is based on the process of input-output transformation, this transformation is measured as an efficiency score relative to the performance frontier (as formed by the set of best performing inter-linked network of nodes). This is in contrast to the general treatment in existing DEA application studies where the production unit is often designated as the DMU in the efficiency evaluation.

2) According to the literature, the definition of a decision making unit can be flexible. While, in most cases, the production unit under evaluation is designated as DMU, the decision maker is not always equivalent to a DMU. In this paper, the decision maker is the port operator but the DMU is the provision of the services in a port. 


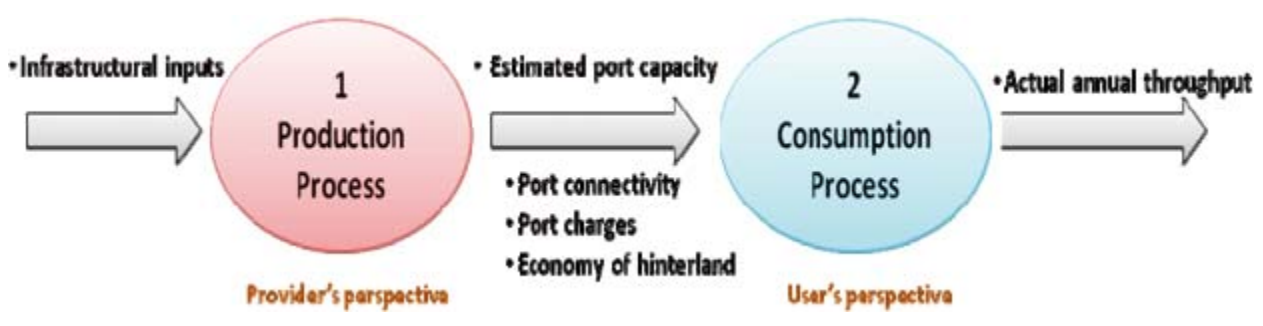

Fig. 1. Conceptual framework

Public transit is similar to liner shipping in its most basic form. As a mode of transportation, it facilitates the passenger movements (instead of cargos) from origin nodes to destination nodes along scheduled routes. Pratt and Lomax (1996), in their study on performance of public transit systems ${ }^{3)}$, highlighted that the performance measures should be in conformance with the objectives that the process is meant to achieve. From the provider's point of view, efficiency in port will be closely associated with achieving objectives such as maximizing the annual revenue or minimizing the total operational costs. The decision maker (the port authorities or port operators in this case) will decide how to vary the inputs to improve the system based on the efficiency score, which indicates of how well the transformation process has been done. Since the inputs considered are infrastructural and port traffic is treated as outputs, an estimated return on port capacity can be obtained. Meanwhile, the user of the port services is the shippers or ocean liners that transport or store containers via the port system. For a major user such as ocean liner, efficient service in a port will be the one that minimizes the vessel turnaround time and container damages. Node 2 represents this perspective in the model.

The proposed model (Fig. 1) links the production process (provider's perspective) and the consumption process (user's perspective) using some common variables being used for both perspectives. For instance, the output from the provider, namely, the "estimated port capacity" is used as inputs in the case of users. From the provider's perspective, limited and costly resources should be used to build a port with facilities that maximize its handling capacity. Therefore, in the production process, the estimated port capacity (i.e., the theoretical throughput given the infrastructural and operational conditions), is used as the parameter for the intermediate output. Higher port capacity is assumed to correlate will higher user satisfaction. This is because low handling capacity will result in costly delay ${ }^{4)}$ for ship owners who can ill afford it.

A summary of the constructs and some of corresponding input variables are given in the graphical illustration in Fig. 2. Variables pertaining to port infrastructures and operations determine the physical capacity of the port; information regarding shipping lines and vessels reflects port network and connectivity; port charges and vessel turnaround time measures the service standards of a port; and institutional factors such port ownership and economic development can also affect port performance. In the recent years, port sustainability (quantified by the amount of emissions and pollution produced) has also become a crucial issue.

The actual annual throughput represents the output for port users, as well as, the final output for the entire system. This actual annual throughput usually differs from the estimated capacity because for the port users also consider other factors, besides handling capacity, when they decide whether to use a specific port or not. These factors include the port

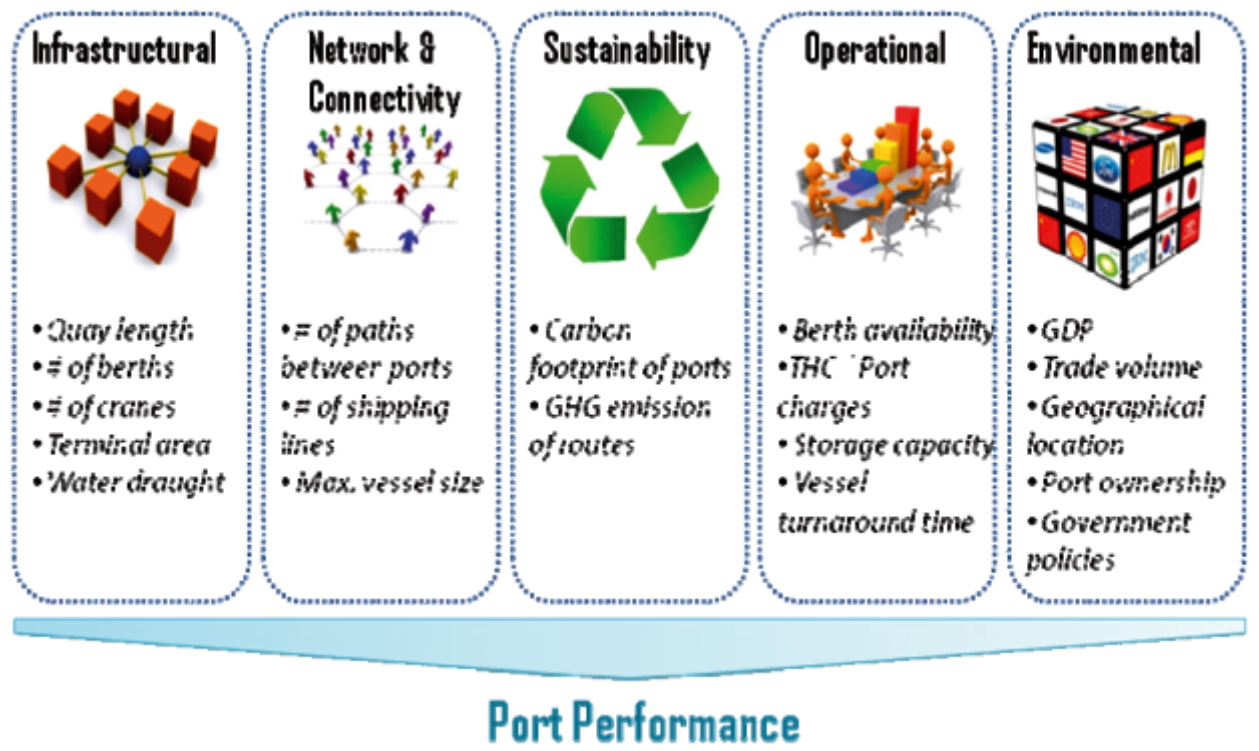

Fig. 2. Factors affecting port performances

3) Prior to Pratt and Lomax, (1996), Fielding et al (1978) have proposed that three elements of transit operations, namely: resource input (labour; capital; fuel, etc.), service output (vehicle-hour; vehicle-km; capacity-km, etc.), and service consumption (passenger trip; passenger-km; operating revenue, etc.) constitute the three corners of a triangle. The three sides of this triangle represent resourceefficiency (measuring service output against resource input), resource-effectiveness (measuring service consumed against resource input), and service-effectiveness (measuring service consumed against service output), respectively.

4) According to Talley (2006), port congestions arise when port users interfere with one another in the utilization of port resources, thereby increasing their time in port and lead to a longer turnaround time for ships. 


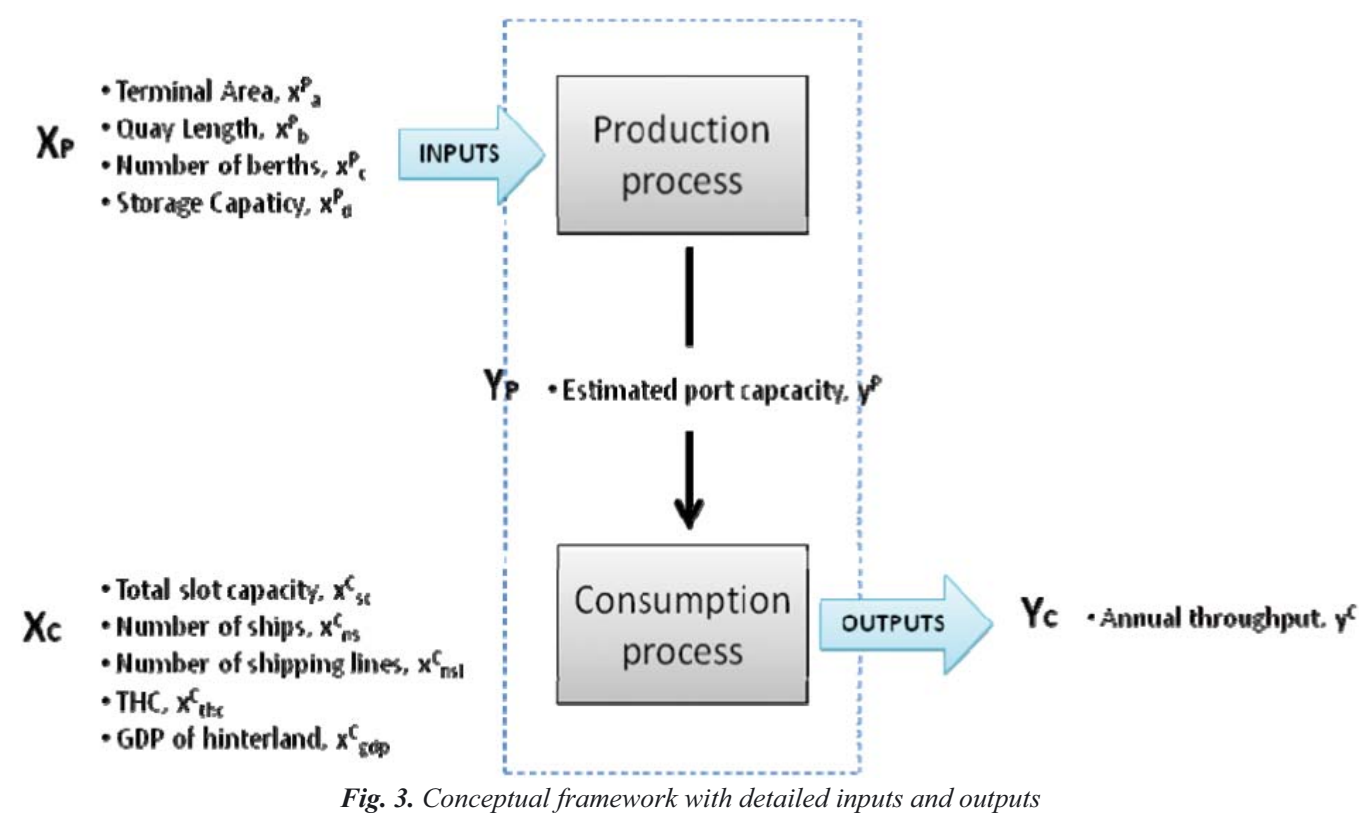

connectivity, charges, locations and economy of the hinterland, etc. As these variables are common influences on shippers' and liner shipping companies' port choice in any geographical locations, they can facilitate the comparison of port services. Hence this also ensures, to certain extent, the generalization of the analysis.

\section{Mathematical Representation}

The network-DEA model is based on three assumptions: first, ports are isolated entities engaging in similar activities and provide comparable range of services; second, container ships are similar in size in terms of transportation capacity; third, uncertainties in the data collected are ignored. Notations for analysis are shown in Fig. 3 together with the model below:

\section{Inputs}

$\mathrm{x}_{\mathrm{ij}}^{\mathrm{P}}$ - inputs for the production process where $\mathrm{i}$ is the $\mathrm{i}^{\text {th }}$ type of input for production in the $\mathrm{j}^{\text {th }}$ port. For instance, $\mathrm{X}^{\mathrm{P}}{ }_{\mathrm{aj}}$ represents "terminal area" as input for production process for port $\mathrm{j}$

$\mathrm{X}_{\mathrm{qj}}^{\mathrm{C}}$ - inputs for the consumption process where $\mathrm{q}$ is the $\mathrm{q}^{\text {th }}$ type of input for consumption in the $\mathrm{j}^{\text {th }}$ port and. For instance, $\mathrm{X}_{\text {gdpj }}^{\mathrm{P}}$ represents "GDP of hinterland" as input for consumption process for port $\mathrm{j}$

\section{Outputs}

$\mathrm{y}_{\mathrm{j}}^{\mathrm{P}}$ - outputs for the production process where $\mathrm{j}$ is the $\mathrm{j}^{\text {th }}$ port. For instance, $\mathrm{y}_{\mathrm{j}}^{\mathrm{P}}$ is the "estimated port capacity" for port $\mathrm{j}$

$\mathrm{y}^{\mathrm{C}}{ }_{\mathrm{j}}$ - outputs for the consumption process where $\mathrm{j}$ is the $\mathrm{j}^{\text {th }}$ port. For instance, $\mathrm{y}_{\mathrm{j}}{ }_{\mathrm{j}}$ is the "actual annual throughput" for port $\mathrm{j}$

\section{Weight Variables}

$\mathrm{u}_{\mathrm{r}} \quad$ - intensity vector associated with output type $\mathrm{r}$

$\mathrm{v}_{\mathrm{i}}$ - intensity vector associated with input type $\mathrm{i}$

$\mathrm{w}_{\mathrm{p}}$ - intensity vector associated with input for consumption process

$\mathrm{w}_{\mathrm{q}}$ - intensity vector associated with intermediate output

Mathematically, the model can be written as follows:

$$
\operatorname{Max} \sum_{\mathrm{r}=1}^{\mathrm{s}} \mathrm{u}_{\mathrm{r}} \mathrm{Y}_{\mathrm{rk}}
$$

Subject to:

$$
\sum_{i=1}^{m} v_{i} v_{i k}^{P}=1
$$

System:

$$
\sum_{\mathrm{r}=1}^{\mathrm{s}} \mathrm{u}_{\mathrm{r}} \mathrm{y}_{\mathrm{rj}}^{\mathrm{C}}-\sum_{\mathrm{i}=1}^{\mathrm{m}} \mathrm{v}_{\mathrm{i}} \mathrm{v}_{\mathrm{ik}}^{\mathrm{P}} \leq 0 \quad \mathrm{i}=\{\mathrm{a}, \mathrm{b}, \mathrm{c}, \mathrm{d}\}
$$

Production process:

$$
\sum_{\mathrm{r}=1}^{\mathrm{s}} \mathrm{w}_{\mathrm{p}} \mathrm{y}_{\mathrm{pj}}^{\mathrm{P}}-\sum_{\mathrm{i}=1}^{\mathrm{m}} \mathrm{v}_{\mathrm{i}} \mathrm{x}_{\mathrm{ij}}^{\mathrm{P}} \leq 0 \quad \mathrm{i}=\{\mathrm{a}, \mathrm{b}, \mathrm{c}, \mathrm{d}\}
$$

\section{Consumption process:}

$$
\sum_{\mathrm{r}=1}^{\mathrm{s}} \mathrm{u}_{\mathrm{p}} \mathrm{y}_{\mathrm{rj}}^{\mathrm{C}}-\sum_{\mathrm{i}=1}^{\mathrm{m}} \mathrm{w}_{\mathrm{q}} \mathrm{x}_{\mathrm{qj}}^{\mathrm{C}} \leq 0 \mathrm{i}=\{\mathrm{sc}, \mathrm{ns}, \mathrm{nsl}, \mathrm{thc}, \mathrm{gpd}, \mathrm{p}\}
$$

Non-negativity constraints:

$$
\mathrm{u}_{\mathrm{r}}, \mathrm{v}_{\mathrm{i}}, \mathrm{w}_{\mathrm{p}}, \mathrm{w}_{\mathrm{q}} \geq 0
$$

The efficiency score is between 0 and 1 . DMUs with the efficiency score equal to 1 are efficient while a DMU with a score of less than 1 is relatively inefficient.

\section{EMPIRICAL ANALYSIS}

\section{Data and Variable Descriptions}

An empirical analysis is conducted on a sample of 30 major seaports world-wide. Based on data availability, the ports are listed below according to the regions where they are located:

- Southeast Asia: Tanjung Priok, Singapore, Port Klang,

Port of Tanjung Pelapas, Laem chabang, Manila

- Northeast Asia:

- China Hong Kong, Shenzhen, Ningbo, Guangzhou, Qingdao, Kaohsiung, Tianjin, Xiamen, Dalian, Shanghai

- Japan: Yokohama, Nagoya, Tokyo

- Korea: Busan

- South Asia: Jawarharlal Nehru, Colombo

- Middle East: Salalah, Dubai

- Europe: Antwerp, Rotterdam, Hamburg, Valencia

- USA: New York, Los Angeles

11 variables, pertaining to various aspects of a maritime logistics chain, are chosen to reflect the decisions of the port 
operators and the users. While port annual throughput as the final output variable chosen coincides with that in the conventional studies (Cullinane and Wang 2007), the input variables are classified into two stages. In the stage of the production process (provider's perspective), infrastructural and operational factors such as number of berths, terminal area, storage capacity and quay length are selected as inputs. With these input variables representing port facilities at the waterside and landside, the provider is expecting the maximum handling capacity from the hardware of the port. On the other hand, in the stage of the consumption process (user's perspective), the actual throughput may differ from the port capacity estimated from the (previous) production process. For a given amount of throughput, a larger number of ships suggests higher frequencies while a smaller number of ships may render greater economies of scale and allows for competitive pricing. Other important aspects that will potentially exert an influence on the perceived attractiveness of a port include port network connectivity ${ }^{5}$, economy of the region $^{6}$, port charges ${ }^{7}$ ) and location ${ }^{8)}$ etc. Table 2 provides a brief description on the variables used in the analysis.

According to Raab and Lichty (2002), the minimum number of DMU observations should be three times greater than the total number of inputs and output. Since this empirical analysis is based on a network-DEA model, for each stage and for the entire system, the aforementioned condition is satisfied [Stage 1: $30 \geq 3(4+1)$; Stage 2: $30 \geq 3(6+1)$; Overall: $30 \geq 3(4+1)$ ]. A complete set of data on all 30 selected ports, sourced from Containerization International YearBook 2010 and Lloyd's World of Ports 2010, can be found in Appendix A.

\section{DEA Results}

The network-DEA model is programmed as a spreadsheet application using MS Excel VBA. Table 3 gives the efficiency scores computed from the traditional DEA-CCR and networkDEA models, as well as, the relative rankings of the ports based on the respective scores.

The efficiency scores obtained from the network-DEA model are rather different from those computed using the traditional CCR model. The network-DEA model reports Hong Kong and Rotterdam as the only two ports that are fully efficient ports. Singapore and Hamburg ports rank the third and fourth, respectively. A number of Chinese ports (i.e., Ningbo, Shenzhen, Tianjin, Qingdao and Shanghai) are also found to be quite efficiency with efficiency scores greater than 0.7. However, Xiamen, Guangzhou and Dalian ports are significantly lagging behind. The efficiency scores in other ports in the Southeast Asia and South Asia region range from 0.25 to 0.57 . Notably, the efficiency scores of 3 Japanese ports are among the lowest below 0.24 with Los Angeles port at the bottom of the list.

On the contrary, the efficiency scores from DEA-CCR model rank Singapore, Dubai and Antwerp as the three best performing ports. Hong Kong, Shanghai, Qingdao and Rotterdam ports are also highly efficient with efficiency scores above 0.9. Three other promising China ports (i.e., Ningbo, Tianjin and Shenzhen) dominate the next band by having efficiency scores between 0.8 and 0.9 . While the most of the ports in the sample obtain reasonable efficiency scores above 0.5 , Tokyo, Yokohama and Manila continue to report efficiency scores below 0.3

Comparing the port rankings under the two respective DEA models, it can be observed that the ports of Hamburg, Salalah, Guangzhou and Rotterdam have shown significant improvements in the network-DEA model. Other ports that exhibit similar tendency are Hong Kong, Shenzhen, Ningbo and Valencia. On the contrary, ports like Antwerp, Dubai, Kaohsiung and Shanghai are ranked better under the DEA-

Tab. 2. Input and output variables used for analysis

\begin{tabular}{|c|c|}
\hline Variables & Description \\
\hline Number of berths & Total number of berths of all terminals \\
\hline Terminal area & Total terminal area in $\mathrm{m}^{2}$ \\
\hline Storage capacity & Total storage capacity of all terminals in TEU \\
\hline Quay length & Total quay length in $\mathrm{m}$ \\
\hline Estimated port capacity & Expected annual throughput in TEU \\
\hline Slot capacity & Total annual slot capacity deployed to/from port in TEU \\
\hline Number of ships & Total number of ships deployed to/from port \\
\hline Number of shipping lines & Number of shipping lines operating in the port \\
\hline GDP & Gross Domestic Product (GDP) of the hinterland in 2008 in billion USD \\
\hline THC & Terminal handling charge for a dry 20 feet container in USD \\
\hline Annual throughput & Annual port throughput In TEU \\
\hline
\end{tabular}

* The numbers of ships and shipping lines, as well as, the GDP of the hinterland provide a rough representation of the locational advantage of the ports.

5) Wang and Cullinane (2006) stated that the accessibility of a container port reflects its competitiveness. Generally, a port is that is more accessible enjoys higher connectivity due to more port calls from major shipping lines.

6) Robinson (2002) and De and Ghosh (2003) remarked that ports that are natural gateway to rich hinterland could be at an advantage compared to ports in small island economies. Similarly, Fleming and Baird (1999) and Loo and Hook (2002) advocated that the presence of a large local market enhances the attractiveness of a port.

7) Chang et al (2008) found that the main haul shipping lines are more sensitive to port costs than feeder service providers. Prior to this, Lirn et al (2004) found handling cost of containers (THC) is the most important attribute under the control of port/terminal operators, which ports can compete on to attract transshipment cargo.

8) Stopford (2009) observed that the closure of centrally located ports, at major trading axes, will result in the route deviations that will increase the average haul. Following that, Low and Tang (2011) advocated that the centrality of a port conveys the degree of indispensability of the port within a liner shipping company's network. 
Tab. 3. Efficiency scores and ranking of scores

\begin{tabular}{|c|c|c|c|}
\hline Seaport & Country & DEA-CCR efficiency & Network DEA efficiency \\
\hline Hong Kong & China & $0.970(4)$ & $1.000(1)$ \\
\hline Rotterdam & Netherlands & $0.902(7)$ & $1.000(1)$ \\
\hline Singapore & Singapore & $1.000(1)$ & $0.979(3)$ \\
\hline Hamburg & Germany & $0.408(23)$ & $0.946(4)$ \\
\hline Ningbo & China & $0.891(8)$ & $0.906(5)$ \\
\hline Shenzhen & China & $0.822(10)$ & $0.883(6)$ \\
\hline Tianjin & China & $0.841(9)$ & $0.877(7)$ \\
\hline Dubai & UAE & $1.000(1)$ & $0.841(8)$ \\
\hline Qingdao & China & $0.930(6)$ & $0.742(9)$ \\
\hline Shanghai & China & $0.950(5)$ & $0.736(10)$ \\
\hline New York & USA & $0.612(12)$ & $0.733(11)$ \\
\hline Salalah & Oman & $0.523(19)$ & $0.718(12)$ \\
\hline Antwerp & Belgium & $1.000(1)$ & $0.645(13)$ \\
\hline Xiamen & China & $0.604(13)$ & 0.607 (14) \\
\hline Guangzhou & China & $0.427(22)$ & $0.575(15)$ \\
\hline Klang & Malaysia & $0.601(14)$ & $0.570(16)$ \\
\hline Busan & South Korea & $0.592(15)$ & $0.554(17)$ \\
\hline Kaohsiung & Taiwan & $0.656(11)$ & $0.543(18)$ \\
\hline Jawaharlal Nehru & India & $0.556(17)$ & $0.536(19)$ \\
\hline Colombo & Sri Lanka & $0.573(16)$ & $0.500(20)$ \\
\hline Tanjung Pelepas & Malaysia & $0.538(18)$ & $0.400(21)$ \\
\hline Tanjung Priok & Indonesia & $0.429(21)$ & $0.380(22)$ \\
\hline Dalian & China & $0.432(20)$ & $0.368(23)$ \\
\hline Laem Chabang & Thailand & $0.324(27)$ & $0.350(24)$ \\
\hline Valencia & Spain & $0.333(26)$ & $0.323(25)$ \\
\hline Manila & Philippines & $0.295(28)$ & $0.250(26)$ \\
\hline Nagoya & Japan & $0.337(25)$ & $0.236(27)$ \\
\hline Yokohama & Japan & 0.285 (29) & $0.220(28)$ \\
\hline Tokyo & Japan & $0.124(30)$ & $0.173(29)$ \\
\hline Los Angeles & USA & $0.353(24)$ & $0.101(30)$ \\
\hline
\end{tabular}

* Figures in the parenthesis indicate the ranking

CCR models. Some possible reasons behind these differences in efficiency performances are discussed in details in the next section.

\section{DISCUSSIONS}

Three interesting observations emerge from the DEA results in the preceding section. Firstly, there appears to be significant differences in performances among the seaports as illustrated from the efficiency scores ranging widely from 0.1 to 1 . This finding is consistent with previous research on global seaports using DEA-CCR model (Tongzon 2001; Park and De 2004; Cullinane et al. 2002). Among the best three performers, the ports are each serving a different region. This points to the fact that port throughput are dependent on the traffic in the region, and capturing a large market share represents a key to efficient operation (possibly owing to the presence of scale economies).

Secondly, the set of fully efficient ports in the DEA-CCR model is different from that in the network DEA model: the ports of Singapore, Dubai and Antwerp are found to have an efficiency score of 1 when the traditional DEA-CCR model is used for evaluation. However, none of these three ports is 100 percent efficient in the network DEA model. Several reasons can be used to explain these differences. When the traditional DEA-CCR model is applied, only the production process (provider's perspective) is considered. As a result, small infrastructural input value with large output value will result in relatively high efficiency scores. Meanwhile, additional factors come into play when the user's perspective is taken into account in the network-DEA model. Apart from port capacity, important considerations such as the accessibility of the port, port charges, geographical location of the port within the liner shipping network affect demand for the available port capacity and determine the utilization of the ports. In the case of Singapore and Antwerp ports, the aggressive strategy pursued by these ports has led to large investment in port capacity. With actual throughputs falling short of the planned port capacity, the Singapore and Antwerp ports report relatively lower efficiency scores in the network-DEA model against the traditional CCR model.

Under the network-DEA model, Hong Kong and Rotterdam are the only two ports deemed to be fully efficient. To some extent, the high port charges in Rotterdam and Hong Kong 
may have ironically helped the ports to boost their efficiency score in the network-DEA model. Rotterdam and Hong Kong ports are gateway ports to the European and Northeast Asia regions. Shippers and liner companies that choose to use the ports perceive that value of port services is more than sufficient to offset the high port charges. Should the ports charge lower port dues, the demand for the port services may exceed the port capacity, leading to congestions and lower efficiency. Among all the ports in the sample, port of Hamburg is seen to increase its efficiency most tremendously under the network-DEA model. The port charges high port dues with a moderate level of GDP for its hinterland, which possibly indicates lower trade volume translating into lower throughput. As infrastructural prices are relatively high in Germany, restricting unwarranted port capacity provision may prove to be beneficial. Hence, the port of Hamburg received a higher efficiency score in the network-DEA model as compared to the DEA-CCR method (which emphasizes primarily on a large throughput).

More interestingly, it could be inferred that congestions in supply chains account for some of the differences observed in performance of ports. For instance, Antwerp port suffers quite a lot as the ring road is extremely congested when Rotterdam has developed a most beneficial strategy as regards the overcoming of this congestion. In other words, conditions of liner shipping 'sharing' the impact of 'number of shipping lines serving a port' is less significant in influencing port performance compared to the presence of congestions in supply chain.

Thirdly, ports reporting low efficiency scores under both the network-DEA and the DEA-CCR models generally fall into two categories. In the first category, the ports suffer from high infrastructural input prices and operating cost. The high cost that is passed onto the port users dampens the demand, and results in low actual throughput. As a consequence, the ports have been underutilized. Especially for the case of Tokyo port, the high port charges have driven users to other cheaper alternative ports. Given the suppressed demand, lower capacity may be more beneficial to the port. The second category consists of ports in developing countries (i.e., Laem Chabang in Thailand and Manila in Philippines). Technological hindrance may limit the handling capacity of the ports, and thus resulting in low efficiency scores.

In a nutshell, the network DEA model provides the port operators with an opportunity to find out the stage of the system where the inefficiency occurs. This can be done by calculating the efficiency of each stage of the system, in this case, the production process or the consumption process. If the former is inefficient, infrastructural and internal operational changes could be made to improve the corresponding process. Meanwhile, if the consumption process is inefficient, port operators should look at the factors influencing user's decisions on port selections and cater their port services to the needs of the users. However, this is likely to be more challenging as some factors may not modifiable, for instance, the location of the port.

\section{CONCLUSIONS}

Port operators and port users are partners for freight transportation in the maritime supply chain. As competitions in the port and maritime escalate, efficiency becomes a central issue to port operators and port users alike. However, definitions for "efficient services" often deviate, if not contradict, between these two parties. From the port operator's viewpoint, efficiency is achieved when the port is able to generate maximum service outputs at the least operating costs (Lee et al. 2005). Whereas according to the user, an efficient port is one that provides quality services such as shortest handling time or minimum damages to the containers at reasonable charges (Murphy and Daley 1994). Therefore, an accurate assessment of port efficiency inexorably requires goals of the port operators and port users to be taken into consideration simultaneously.

This paper proposes a network-DEA model to evaluate the efficiencies of 30 major ports (spanning across Asia, Middle East, Europe and North America), which form an important pillar in global seaborne-freight transport. The proposed network DEA model is capable of capturing the intricate relationships between the provider and the consumer of the port services and integrating their goals in a single efficiency score for the evaluation of port services. The efficiency score will be high only if this relationship is adequately balanced: when the estimated port capacity (intermediate output) is greater than the actual throughput (final output), the port may be under-utilized due to factors adversely influencing the user's decisions; and when the estimated capacity is equal or smaller, the efficiency score may be still low and indicates that the demand for port services is higher than expected.

Our results show that the port of Hong Kong and Rotterdam are the most efficient port systems when the perspectives of both the providers and users are taken into account under the network DEA model. It is also meaningful to note that the network-DEA model and the traditional CCR-DEA model produce two sets of very different efficiency scores. While most of the CCR scores are higher than the corresponding network DEA efficiency, some ports such the ports of Salalah and Hamburg show significant increase in efficiency when using network-DEA model for evaluation. Hence, the concurrent consideration of efficiency scores from the network-DEA model and the traditional DEA-CCR model will offer valuable insights to port operators on how to improve the efficiency of the port (i.e., at which stage of the maritime supply chain that inefficiencies occur).

Admittedly, there have been some limitations in this study. Firstly, owing to the difficulty in accurate quantifications, technological supporting system that enhances the handling efficiency in ports to the same effect of larger infrastructural investment is not explicitly taken into account. Similarly, important measures of quality of port services such as vehicle loading and unloading service rates, vehicle turn-around time, berth and channel reliability (accessibility) are omitted due to the lack of data. Secondly, port charges are approximated using THCs (which is defined in Fung et al (2003) as fees charged by shipping lines and paid by shippers for moving containers between container terminals (or the shore) and ships). Such treatment is justified on the observation that the THC, in most cases, is proportional to the total port charge and thus it represents well this parameter. Thirdly, GDP of hinterland is used as a proxy for the trade volume in the region. This simplification is imposed because it is difficult to delineate the boundaries of the hinterlands, especially with the logistical developments that have led to their overlapping. Nonetheless, we recognize that trade volume of respective regions should be used instead.

For future research, it would be meaningful to extend this study to consider the negative externalities as an undesirable environmental output of the consumption process when measuring the performances of ports.

\section{Acknowledgements}

The authors are grateful to the four anonymous reviewers for their invaluable suggestions to improve the earlier version of this paper. 


\section{Appendix A}

Tab. A-1. Literature Taxonomy on Port Efficiency Studies

\begin{tabular}{|c|c|c|c|c|}
\hline Reference & Sample & Method & Inputs & Outputs \\
\hline Roll and Hayuth (1993) & 20 hypothetical ports & DEA-CCR model & $\begin{array}{l}\text { Manpower, capital, } \\
\text { cargo uniformity }\end{array}$ & $\begin{array}{l}\text { Cargo throughput, level } \\
\text { of service, consumer } \\
\text { satisfaction, ship calls }\end{array}$ \\
\hline Liu (1995) & $\begin{array}{c}28 \text { British port } \\
\text { authorities, 1983-1990 }\end{array}$ & $\begin{array}{l}\text { Translog production } \\
\text { function }\end{array}$ & Movement of freight & Turnover \\
\hline $\begin{array}{c}\text { Martinez Budria, Diaz } \\
\text { Armas, Navarro Ibánez } \\
\text { and Ravello Mesa } \\
\text { (1999) }\end{array}$ & $\begin{array}{c}26 \text { Spanish ports, } 1993- \\
1997\end{array}$ & DEA-BCC model & $\begin{array}{l}\text { Labour costs, } \\
\text { depreciation charges, } \\
\text { other costs }\end{array}$ & $\begin{array}{l}\text { Total cargo moved } \\
\text { through docks, revenue } \\
\text { obtained from rent of } \\
\text { port facilities }\end{array}$ \\
\hline $\begin{array}{c}\text { Coto Millán,Bańos } \\
\text { Pino and Rodriguez } \\
\text { Alvarez }(2000)\end{array}$ & $\begin{array}{l}27 \text { Spanish ports, 1985- } \\
1989\end{array}$ & Translog cost model & Cargo handled & $\begin{array}{l}\text { Aggregate port output, } \\
\text { including total total } \\
\text { goods moved and the } \\
\text { passenger embarked } \\
\text { and disembarked and } \\
\text { the number of vehicles } \\
\text { with passengers }\end{array}$ \\
\hline Tongzon (2001) & $\begin{array}{c}4 \text { Austrailian and } 12 \\
\text { other international } \\
\text { ports, } 1996\end{array}$ & $\begin{array}{l}\text { DEA-CCR additive } \\
\text { model }\end{array}$ & $\begin{array}{l}\text { Number of cranes, } \\
\text { container berths, tugs, } \\
\text { terminal area, delay } \\
\text { time, labour }\end{array}$ & $\begin{array}{l}\text { Cargo throughput, ship } \\
\text { working rate }\end{array}$ \\
\hline $\begin{array}{l}\text { Estache, Gonzalez and } \\
\text { Trujillo (2001) }\end{array}$ & $\begin{array}{c}14 \text { Mexican ports, } \\
1996-1999\end{array}$ & $\begin{array}{l}\text { Translog and Cobb- } \\
\text { Douglas production } \\
\text { frontier model }\end{array}$ & Containers handled & $\begin{array}{c}\text { Volume of merchandise } \\
\text { handled }\end{array}$ \\
\hline $\begin{array}{l}\text { Cullinane, Song and } \\
\text { Gray (2002) }\end{array}$ & $\begin{array}{l}15 \text { Asian container } \\
\text { ports, 1989-1998 }\end{array}$ & $\begin{array}{c}\text { Stochastic Cobb- } \\
\text { Douglas production } \\
\text { frontier: half normal, } \\
\text { exponential, truncated } \\
\text { models }\end{array}$ & Number of employees & $\begin{array}{l}\text { Annual container } \\
\text { throughput }\end{array}$ \\
\hline Itoh (2002) & $\begin{array}{c}8 \text { Japanese ports, 1990- } \\
1999\end{array}$ & $\begin{array}{l}\text { DEA-CCR and } \\
\text { BCC with window } \\
\text { application }\end{array}$ & $\begin{array}{l}\text { Port infrastructure, port } \\
\text { superstructure, labour }\end{array}$ & $\begin{array}{l}\text { Total annual container } \\
\text { throughput }\end{array}$ \\
\hline $\begin{array}{l}\text { Cullinane and Song } \\
\qquad(2003)\end{array}$ & $\begin{array}{l}5 \text { container terminals in } \\
\text { Korea and UK, } 1998\end{array}$ & $\begin{array}{c}\text { Stochastic Cobb- } \\
\text { Douglas production } \\
\text { frontier: half normal, } \\
\text { exponential, truncated } \\
\text { models }\end{array}$ & Fixed capital & $\begin{array}{l}\text { Turnover derived } \\
\text { from the provision } \\
\text { of container terminal } \\
\text { services, excluding } \\
\text { property sales }\end{array}$ \\
\hline Barros (2003a) & $\begin{array}{c}5 \text { Portuguese ports, } \\
1990-2000\end{array}$ & $\begin{array}{l}\text { DEA -allocative and } \\
\text { Technical efficiency }\end{array}$ & $\begin{array}{l}\text { Number of employees, } \\
\text { book value of assets }\end{array}$ & $\begin{array}{l}\text { Ships, movement } \\
\text { of freight, gross } \\
\text { tonnage, market share, } \\
\text { break-bulk cargo, } \\
\text { containerized cargo, } \\
\text { dry bulk, liquid bulk, } \\
\text { net income prices, }\end{array}$ \\
\hline Barros (2003b) & $\begin{array}{c}10 \text { Portuguese ports, } \\
1990-2000\end{array}$ & $\begin{array}{l}\text { DEA-Malmquist index } \\
\text { and a Tobit model }\end{array}$ & $\begin{array}{l}\text { Number of employees, } \\
\text { book value of assets }\end{array}$ & $\begin{array}{l}\text { Ships, , movement of } \\
\text { freight, break-bulk } \\
\text { cargo, containerized } \\
\text { cargo, dry bulk, liquid } \\
\text { bulk }\end{array}$ \\
\hline Park and De (2004) & 11 Korean ports, 1999 & $\begin{array}{l}\text { DEA-CCR and BCC } \\
\text { model }\end{array}$ & $\begin{array}{l}\text { Berthing capacity and } \\
\text { cargo handling }\end{array}$ & $\begin{array}{l}\text { Cargo throughputs, } \\
\text { number of ship calls, } \\
\text { revenue and consumer } \\
\text { satisfaction }\end{array}$ \\
\hline
\end{tabular}




\begin{tabular}{|c|c|c|c|c|}
\hline Reference & Sample & Method & Inputs & Outputs \\
\hline $\begin{array}{l}\text { Barros and Athanassiou } \\
\text { (2004) }\end{array}$ & $\begin{array}{l}2 \text { Greek and } 4 \\
\text { Portuguese ports }\end{array}$ & $\begin{array}{l}\text { DEA-CCR and BCC } \\
\text { model }\end{array}$ & Labour and capital & $\begin{array}{l}\text { Number of ships, } \\
\text { movement of freight, } \\
\text { cargo handled, } \\
\text { container handled }\end{array}$ \\
\hline $\begin{array}{l}\text { Bonilla, Casasus et al. } \\
\text { (2004) }\end{array}$ & $\begin{array}{l}23 \text { Spanish ports, 1995- } \\
1998\end{array}$ & $\begin{array}{l}\mathrm{CCR}, \mathrm{BCC} \text { and } \\
\text { Imprecise DEA }\end{array}$ & $\begin{array}{c}\text { General available } \\
\text { equipment }\end{array}$ & $\begin{array}{c}\text { Total liquid, } \\
\text { breakbulk and general } \\
\text { commodities cargo in } \\
\text { Ktons }\end{array}$ \\
\hline $\begin{array}{l}\text { Turner, Windle et al. } \\
\qquad(2004)\end{array}$ & $\begin{array}{c}36 \text { continental US and } \\
\text { Canadian container } \\
\text { ports, 1984-1997 }\end{array}$ & $\begin{array}{l}\text { DEA-CCR with Tobit } \\
\text { regression on industry } \\
\text { structure, port authority } \\
\text { conduct, ocean carrier } \\
\text { conduct, situational } \\
\text { factors and control } \\
\text { variables }\end{array}$ & $\begin{array}{l}\text { Total terminal area, } \\
\text { number of quayside } \\
\text { gantry cranes, berth } \\
\text { length }\end{array}$ & Container throughput \\
\hline $\begin{array}{l}\text { Cullinane, Song and } \\
\text { Wang (2005) }\end{array}$ & $\begin{array}{c}57 \text { international } \\
\text { container ports, } 1999\end{array}$ & $\begin{array}{l}\text { DEA-CCR, DEA-BCC } \\
\text { and DEA-FHD models }\end{array}$ & $\begin{array}{c}\text { Terminal length, } \\
\text { terminal area, quayside } \\
\text { gantry, yard gantry and } \\
\text { straddle carries }\end{array}$ & Container throughput \\
\hline $\begin{array}{l}\text { Tongzon and Heng } \\
\text { (2005) }\end{array}$ & $\begin{array}{l}25 \text { international } \\
\text { container ports }\end{array}$ & $\begin{array}{l}\text { Stochastic Cobb- } \\
\text { Douglas model and } \\
\text { a competitiveness } \\
\text { regression, with } \\
\text { restriction to the } \\
\text { frontier equation }\end{array}$ & $\begin{array}{l}\text { Terminal quay length, } \\
\text { number of quay cranes, } \\
\text { port size }\end{array}$ & Container throughput \\
\hline Barros (2005) & $\begin{array}{c}10 \text { Portuguese ports, } \\
1990-2000\end{array}$ & $\begin{array}{l}\text { Stochastic translog cost } \\
\text { frontier }\end{array}$ & $\begin{array}{l}\text { Price of labour, price } \\
\text { of capital, ships, cargo, } \\
\text { trend }\end{array}$ & Total costs \\
\hline $\begin{array}{l}\text { Cuillinane, Wang, Song } \\
\text { and Ji (2006) }\end{array}$ & $\begin{array}{c}28 \text { international } \\
\text { container ports, } 1983- \\
1990\end{array}$ & $\begin{array}{c}\text { Stochastic Cobb- } \\
\text { Douglas and DEA } \\
\text { model }\end{array}$ & $\begin{array}{l}\text { Terminal length, } \\
\text { terminal area, quayside } \\
\text { gantry, yard gantry and } \\
\text { straddle carries }\end{array}$ & $\begin{array}{l}\text { Annual container } \\
\text { throughput }\end{array}$ \\
\hline $\begin{array}{l}\text { Cuillinane and Wang } \\
\qquad(2006)\end{array}$ & $\begin{array}{l}69 \text { European container } \\
\text { ports, } 2002\end{array}$ & $\begin{array}{l}\text { Output oriented DEA- } \\
\text { CCR and DEA-BCC }\end{array}$ & $\begin{array}{l}\text { Quay length, terminal } \\
\text { area, number of } \\
\text { equipment }\end{array}$ & $\begin{array}{l}\text { Annual container } \\
\text { throughput }\end{array}$ \\
\hline $\begin{array}{l}\text { Cuillinane and Wang } \\
\qquad(2006)\end{array}$ & $\begin{array}{l}104 \text { European container } \\
\text { ports }\end{array}$ & $\begin{array}{l}\text { Output oriented DEA- } \\
\text { CCR and DEA-BCC } \\
\text { with Tobit regression }\end{array}$ & $\begin{array}{c}\text { Quay length, terminal } \\
\text { area and equipment } \\
\text { cost }\end{array}$ & $\begin{array}{l}\text { Annual container } \\
\text { throughput }\end{array}$ \\
\hline Fu, Song et al. (2007) & 10 China ports & $\begin{array}{l}\text { DEA based evaluation } \\
\text { of Malmquist } \\
\text { Productivity Index with } \\
\text { PCA }\end{array}$ & $\begin{array}{c}\text { Number of berths, } \\
\text { quay length, yard } \\
\text { area, number of } \\
\text { gantry cranes, GDP } \\
\text { of hinterland, value } \\
\text { of second industry of } \\
\text { hinterland }\end{array}$ & $\begin{array}{l}\text { Annual container } \\
\text { throughput, number of } \\
\text { shipping lanes, number } \\
\text { of liner ships calls }\end{array}$ \\
\hline Liu (2008) & 10 ports in Asia Pacific & $\begin{array}{c}\text { DEA-CCR, DEA- } \\
\text { BCC and 3-stage DEA } \\
\text { model }\end{array}$ & $\begin{array}{l}\text { Container lot size, } \\
\text { number of bridge } \\
\text { cranes, deepwater } \\
\text { berths, length of berth }\end{array}$ & $\begin{array}{c}\text { Annual container } \\
\text { throughput, number of } \\
\text { port calls }\end{array}$ \\
\hline $\begin{array}{l}\text { Herrera and Pang } \\
\qquad(2008)\end{array}$ & $\begin{array}{l}82 \text { international } \\
\text { container ports }\end{array}$ & $\begin{array}{l}\text { DEA-CCR, DEA-BCC } \\
\text { and FDH model }\end{array}$ & Land, equipment & $\begin{array}{l}\text { Annual container } \\
\text { throughput }\end{array}$ \\
\hline
\end{tabular}




\begin{tabular}{|c|c|c|c|c|}
\hline Reference & Sample & Method & Inputs & Outputs \\
\hline Sharma and Yu (2009) & $\begin{array}{l}70 \text { international } \\
\text { container terminals }\end{array}$ & $\begin{array}{l}\text { DEA-CCR and DEA- } \\
\text { BCC with Kohonen's } \\
\text { self-organizing maps } \\
\text { for performance } \\
\text { clustering }\end{array}$ & $\begin{array}{l}\text { Quay length, terminal } \\
\text { area, number of quay } \\
\text { cranes, yard cranes, } \\
\text { straddle carriers and } \\
\text { stacker vehicles }\end{array}$ & $\begin{array}{l}\text { Annual container } \\
\text { throughput }\end{array}$ \\
\hline Low (2010) & $\begin{array}{l}23 \text { major Asian ports, } \\
2008\end{array}$ & $\begin{array}{c}\text { CCR, BCC, Slack- } \\
\text { based measure, } \\
\text { congestion, measure } \\
\text { specific }\end{array}$ & $\begin{array}{l}\text { the number of gantry } \\
\text { cranes, } \\
\text { terminal area, quay } \\
\text { length and draft }\end{array}$ & $\begin{array}{l}\text { Annual container } \\
\text { throughput, tons of } \\
\text { bulk cargo and the } \\
\text { number of ship calls }\end{array}$ \\
\hline Chin and Low (2010) & 13 Asian ports, 2009 & $\begin{array}{c}\text { CCR, BCC, Slack- } \\
\text { based measure models }\end{array}$ & $\begin{array}{l}\text { Frequency of shipping } \\
\text { services, } \\
\text { Bilateral trade flows }\end{array}$ & $\begin{array}{l}\text { Annual container } \\
\text { capacity flows between } \\
\text { ports, nitrogen oxide, } \\
\text { sulphur, carbon } \\
\text { dioxide, and particulate } \\
\text { emissions }\end{array}$ \\
\hline
\end{tabular}

Appendix B: Port Data

\begin{tabular}{|c|c|c|c|c|c|c|c|c|c|c|}
\hline & Singapore & Shanghai & Hong Kong & Shenzhen & Busan & Dubai & Ningbo & Guangzhou & Qingdao & Kaohsiung \\
\hline Terminal Area (m2) & 3890000 & 8569837 & 2794500 & 3550800 & 2799300 & 1621050 & 1957000 & 4650000 & 836800 & 1821374 \\
\hline Quay length (m) & 10754 & 8956 & 8841 & 8923 & 11835 & 6263 & 4138 & 5219 & 5449 & 6714 \\
\hline Storage Capacity (TEU) & 300000 & 420084 & 255238 & 223217 & 230523 & 101876 & 127045 & 292805 & 117872 & 90584 \\
\hline Number of berths & 44 & 30 & 25 & 12 & 11 & 10 & 19 & 16 & 26 & 19 \\
\hline Total Slot Capacity (TEU) & 3495215 & 4882737 & 4606177 & 2219426 & 2426863 & 1437928 & 3677906 & 1395068 & 3868143 & 2143715 \\
\hline Total Ships Deployed & 927 & 1123 & 1017 & 510 & 634 & 335 & 846 & 321 & 889 & 514 \\
\hline No. of Shipping Lines & 88 & 77 & 80 & 35 & 81 & 13 & 58 & 22 & 61 & 58 \\
\hline Expected Port Capacity (TEU) 2008 & 35000000 & 34000000 & 19000000 & 20000000 & 15000000 & 15000000 & 11000000 & 11500000 & 15000000 & 10200000 \\
\hline THC Dry20' (\$) & 133.8 & 58.6 & 270.3 & 150.0 & 90.4 & 175.6 & 58.6 & 150.0 & 58.6 & 166.7 \\
\hline GDP 2008 (\$\$bn) & 215.0 & 233.0 & 320.0 & 114.3 & 121.0 & 80.0 & 58.1 & 143.0 & 65.0 & 45.0 \\
\hline Throughput (TEU) 2008 & 29918200 & 27980000 & 24248000 & 21413888 & 13425000 & 11827299 & 11226000 & 11001300 & 10320000 & 9676554 \\
\hline & Tianjin & \multicolumn{3}{|c|}{ Port Klang anjung Pelepa Laem Chabang } & Xiamen & Dalian & Tanjung Priok & lawaharlal Nehru & Colombo & Yokohama \\
\hline Terminal Area (m2) & 1292400 & 1736300 & 1200000 & 2445800 & 1065000 & 1648579 & 1656000 & 1208400 & 672300 & 2388922 \\
\hline Quay length (m) & 3472 & 5279 & 5140 & 5600 & 2753 & 3536 & 3192 & 2437 & 2886 & 6000 \\
\hline Storage Capacity (TEU) & 138350 & 120800 & 200000 & 161150 & 129387 & 124468 & 119140 & 93500 & 62320 & 124062 \\
\hline Number of berths & 12 & 21 & 6 & 27 & 6 & 11 & 14 & 7 & 10 & 18 \\
\hline Total Slot Capacity (TEU) & 1014595 & 2557643 & 557435 & 488257 & 1648716 & 3107196 & 179113 & 846573 & 980245 & 1766131 \\
\hline Total Ships Deployed & 233 & 630 & 137 & 207 & 379 & 714 & 154 & 306 & 241 & 540 \\
\hline No. of Shipping Lines & 16 & 78 & 17 & 48 & 26 & 49 & 41 & 46 & 53 & 68 \\
\hline Expected Port Capacity (TEU) 2008 & 8500000 & 7740000 & 8000000 & 11000000 & 5034600 & 4502700 & 3500000 & $4,400,000$ & 5300000 & 3481485 \\
\hline THC Dry20' (\$) & 54.2 & 101.8 & 66.9 & 78.3 & 58.6 & 60.1 & 120.0 & 88.6 & 151.0 & 324.2 \\
\hline GDP 2008 (Șbon) & 74.0 & 361.2 & 361.2 & 273.0 & 22.9 & 56.5 & 92.0 & 164.0 & 39.6 & 271.0 \\
\hline Throughput(TEU) 2008 & 8500000 & 7970000 & $5,600,000$ & 5133930 & 5034600 & 4502700 & 3984278 & $3,952,735$ & 3687465 & 3481485 \\
\hline
\end{tabular}




\begin{tabular}{|c|c|c|c|c|c|c|c|c|c|c|}
\hline & Tokyo & Salalah & Manila & Nagoya & Rotterdam & Hamburg & Los Angeles & New York & Antwerp & Valencia \\
\hline Terminal Area (m2) & 1883150 & 765000 & 1821980 & 1511475 & 6881600 & 5384000 & 6477336 & 5566100 & 7434073 & 1612300 \\
\hline Quay length (m) & 5179 & 2205 & 3556 & 4105 & 4900 & 5700 & 3302 & 3615 & 2000 & 3675 \\
\hline Storage Capacity (TEU) & 285020 & 58090 & 59821 & 72922 & 81000 & 149600 & 104006 & 48323 & 196988 & 88046 \\
\hline Number of berths & 13 & & 54 & 13 & 25 & 35 & 25 & 36 & 33 & 5 \\
\hline Total Slot Capacity (TEU) & 1298626 & 850173 & 117651 & 1480434 & 1580000 & 2200000 & 1397400 & 1146080 & 970000 & 780000 \\
\hline Total Ships Deployed & 397 & 159 & 81 & 453 & 305 & 106 & 200 & 180 & 121 & 98 \\
\hline No. of Shipping Lines & 50 & 16 & 30 & 57 & 32 & 90 & 76 & 24 & 30 & 19 \\
\hline Expected Port Capacity (TEU) 2008 & 3700000 & 6000000 & 1500000 & 2500000 & 13000000 & 12000000 & 8400000 & 5300000 & 15000000 & 3500000 \\
\hline THC Dry20' (\$) & 324.2 & 75.0 & 110.0 & 324.2 & 219.6 & 260.8 & 198.0 & 198.0 & 178.4 & 206.6 \\
\hline GDP 2008(\$\$bn) & 1479.0 & 68.3 & 149.0 & 297.5 & 877.0 & 118.2 & 792.0 & 1144.0 & 390.5 & 141.1 \\
\hline Throughput (TEU) 2008 & 3083266 & 3068000 & 2977606 & 2816827 & 10783825 & 9737000 & 8081000 & 5300000 & 8663000 & 3042665 \\
\hline
\end{tabular}

\section{REFERENCES}

1. Bańos Pino, J.; Coto Millán, P and Rodriguez Alvarez, A (2000). Allocative efficiency and overcapitalization: na application. International Journal of Transport Economics, 2, 181-199.

2. Barros C. P and M. Athanassious. (2004). Efficiency in European Seaports with DEA: Evidence from Greece and Portugal. Maritime Economics and Logistics, 6, 122-140.

3. Barros, C. P. (2003a). Incentive Regulation and Efficiency of Portuguese Port Authorities. Maritime Economics and Logistics, 5(1), 55-69.

4. Barros, C. P. (2003b). The Measurement of Efficiency of Portuguese Seaport Authorities with DEA. International Journal of Transport Economics, 30(3), 335-354.

5. Barros, C. P. (2005). Decomposing Growth in Portuguese Seaports: A Frontier Cost Approach. Maritime Economics and Logistics, 7(4), 297- 315.

6. Bonilla, M.; T. Casasus et al. (2004). An efficiency analysis with tolerance to the Spanish port system. International Journal of Transport Economics, 31(3), 379-400.

7. Clark, X.; Dollar, D. and Micco, A. (2004). Port efficiency, maritime transport costs and bilateral trade. Journal of Development Economics, 75(2), 417-450

8. Chang, Y.T., Lee, S.Y. and Tongzon, J.L. (2008). Port selection factors by shipping lines: Different perspectives between trunk liners and feeder service providers, Marine Policy, 32, 877-885

9. Coto Millán, P.; Bańos Pino, J. and Rodriguez Alvarez, A (2000). Economic Efficiency in Spanish Ports: Some Empirical Evidence. Maritime Policy and Management, 27(2), 169-175.

10.Cullinane, K.; P. Ji et al. (2005). The relationship between privatization and DEA estimates of efficiency in the container port industry. Journal of Economics and Business, 57, 433-462.

11.Cullinane, K.P.B., Song, D. W and Gray, R. (2002). A Stochastic Frontier Model of the Efficiency of Major Container Terminals in Asia: Assessing the influence of administrative and ownership structures. Transportation Research, 36A, 734-762.

12.Cullinane, K.P.B. and Song, D. W. (2003). A Stochastic Frontier Model of the Productive Efficiency of Korean Container Terminals. Applied Economics, 35(3), 251-267.

13.Cullinane, K., Song, D.W, Wang, T. (2005). The application of Mathematical Programming Approaches to Estimating Container Port Production Efficiency. Journal of Productivity Analysis, 24, 73-92.

14.Cullinane, K., Wang, T. et al. (2006). The efficiency of European container ports: a cross-sectional data envelopment analysis. International Journal of Logistics, Research and Application, 9(1), 19-31.
15.Cullinane, K., Wang, T.F., Song, D. W and Ji, P. (2006). The technical efficiency of Container Ports: Comparing Data Envelopment Analysis and Stochastic Frontier Analysis. Transportation Research, 40A, 354-374.

16.Cullinane, K., and Wang, T.F. (2007). Data envelopment analysis and improving port container efficiency. Research in Transportation Economics, 17, 517-566

17.De, P. and Ghosh, B. (2003). Productivity, efficiency and technological change in Indian ports, International Journal of Maritime Economics, 4, 348 - 368.

18.Estache, A., Gonzalez, M. and Trujillo, L. (2001). Efficiency Gains from Port Reforms and the Potential for yardstick Competition: Lessons from Mexico. World Development, 30(4), 545-560.

19.Fleming, D. K. and Baird, A.J. (1999). Some reflections on port competition in the United States and Western Europe. Maritime Policy and Management, 26(4), 383 - 394

20.Fielding, G.J., Glauthier, R.E., Lave, C.A. (1978). Performance indicators for transit management. Transportation 7 (4), 365379.

21.Fu, B. X.; X. Q. Song et al. (2007). Study on improved DEA based MPI and its application in dynamic performance evaluation. $14^{\text {th }}$ International Conference on Management Science and Engineering, Harbin, Peoples R China.

22.Fung, M.K., Cheng, L.K., and Qiu, L.D. (2003). The impact of terminal handling charges on overall shipping charges: an empirical study. Transportation Research 37A, 703-716

23.Itoh, H. (2002). Efficiency changes at major container ports in Japan: A window application of data envelopment analysis. Review of Urban and Regional Development Studies, 14(2), 133-152.

24.Lee, H.S., Chou, M.T., and Guo, S.G. (2005). Evaluating port efficiency in Asia Pacific region with recursive data envelopment analysis. Journal of the Eastern Asia Society for Transportation Studies, 6, 544 - 559

25.Liu, C. C. (2008). Evaluating the operational efficiency of major ports in the Asia-Pacific region using data envelopment analysis. Applied Economics, 40(14), 1731-1743.

26.Liu, Z. (1995). The Comparative Performance of Public and Private Enterprises. Journal of Transport Economics and Policy, 29(3), 263-274.

27.Lirn, T.C., Thanopoulou, H.A., Beynon, M.J., and Beresford, A.K.C (2004) An Application of AHP on Transhipment Port Selection: A Global Perspective, Maritime Economics and Logistics, 6, 70-91

28.Loo, B.P.Y. and Hook, B. (2002). Interplay of international, national and local factors in shaping container port 
development: a case study of Hong Kong, Transport Reviews, 22 (2), $219-245$.

29.Low, J.M.W. (2010). Capacity investment and efficiency cost estimations in major East Asian ports. Maritime Economics and Logistics 12, 370-391.

30.Low, J.M.W and Tang, L.C (2011). Network effects in Asian container port industry, Maritime Policy and Management, forthcoming

31.Martinez Budria, E.; Diaz Armas, R.; Navarro Ibafiez, M and Ravelo Mesa, T. (1999). A Study of the Efficiency of Spanish Port Authorities Using Data Envelopment Analysis. International Journal of Transport Economics, 2, 237-253.

32.Murphy, P.R. and Daley, J.M. (1994). A comparative analysis of port selection factors. Transportation Journal, 34, $15-21$

33.Nagorski, B. (1976). Port problems in developing countries: Principles of port planning and organization. In International Association of Ports and Harbors,

34.Park, R. K. and De, Prabir (2004). An Alternative Approach to Efficiency Measurement of Seaports. Maritime Economics and Logistics, 6, 53-69.

35.Robinson, R. (2002). Ports as elements in value-driven chain systems - the new paradigm, Maritime Policy and Management, $29,241-255$

36.Roll, Y. and Hayuth, Y. (1993). Port Performance Comparison Applying Data Envelopment Analysis (DEA). Maritime Policy and Management, 20(2), 153-161.

37.Herrera, S., and Pang, G. (2008). Efficiency of infrastructure: the case of container ports. Available at http://www.anpec.org. br/revista/vo19/vol9n1p165_194.pdf

38.Sharma, M. J. and. Yu, S. J. (2009). Performance based stratification and clustering for benchmarking of container terminals. Expert Systems with Applications, 36(3), 5016-5022.

39.Song, D. W. and Cullinane, K. (2001). The Administrative and Ownership Structure of Asian Container Ports. International Journal of Maritime Economics, 3(2), 175-197.

40.Stopford, M. (2009). Maritime Economics, third edition, Abingdon: Routledge

41.Talley, W. (2006). Economic theory of a port, in K. Cullinane and W. Talley (Ed.) Research in Transportation Economics, 16, 43- 66
42.Tongzon, J and Heng, W. (2005). Port Privatization, Efficiency and Competitiveness: Some Empirical Evidence from Container Ports (terminals). Transportation Research 39A, 405-424.

43.Tongzon J. (2001). Efficiency Measurement of Selected Australian and Other international Ports using DEA. Transportation Research 35A, 113-128.

44.Turner, H., R. Windle, et al. (2004). North American container port productivity: 1984-1997. Transportation Research 40E, 339-356.

45.Wang, T. and Cullinane, K. (2006a). The efficiency of European container terminal and implications for supply chain management. Maritime Economics and Logistics, 8, 82-99.

46.Wang, Y., Cullinane, K. (2006b). Inter-port competition and measures of individual container port accessibility, International Association of Maritime Economist Conference, Melbourne Australia, 12-14 July

47.Zhu, J. (2009). Quantitative Models for Performance Evaluation and Benchmarking: Data Envelopment Analysis with Spreadsheets, Kluwer Academic Publishers, Boston.

\section{CONTACT WITH THE AUTHORS}

Joyce M.W Low*, Ph.D., Senior Lecturer School of Air Transportation and Logistics, Korea Aerospace University

100 Hanggongdae-gil, Hwajeon-dong, Deogyang-Gu, Goyang-City, Gyeonggi-Do, 412-791, Republic of Korea e-mail: joanphan@gmail.com; phone: +82-2-300-0374

Shao Wei Lam, Ph.D.

Loon Ching Tang, Ph.D. Professor Zhang Lan, B. Eng.

Department of Industrial and Systems Engineering, National University of Singapore

10 Kent Ridge Crescent, Singapore 119260

* Corresponding author 